\title{
Analisis Kesulitan Guru PPKn dalam Mengembangkan Materi Pembelajaran Bhinneka Tunggal Ika
}

\author{
Winarno ${ }^{1}$, Rusnaini, Moh. Muchtarom, Erna Yuliandari, Machmud Al Rasyid, Anis Suryaningsih \\ Prodi Pendidikan Pancasila dan Kewarganegaraan, Fakultas Keguruan dan Ilmu Pendidikan, \\ Universitas Sebelas Maret, Surakarta, Indonesia \\ ${ }^{1}$ winarnonarmoatmojo@staff.uns.ac.id
}

\begin{abstract}
ABSTRAK
Penelitian ini bertujuan mengidentifikasi dan menganalisis kesulitan guru PPKn SMP dalam mengembangkan materi pembelajaran Bhinneka Tunggal Ika yang berbasis isu aktual. Metode yang digunakan deskriptive kualitatif. Teknik pengumpulan data menggunakan wawancara dengan informan guru PPKn SMP Kabupaten Sukoharjo dan pakar bidang PKn, analisis dokumen terhadap buku ajar PPKn SMP dan dokumen kurikulum PPKn 2013, ditunjang dengan Focus Group Discussion. Hasil penelitian menunjukkan bahwa guru tidak mengalami kesulitan mengembangkan materi aspek Bhinneka Tunggal Ika PPKn SMP dikarenakan sudah mendasarkan pada buku ajar pemerintah dan RPP yang dikembangkan MGMP PPKn SMP Kabupaten Sukoharjo. Kesulitan dialami pada saat menyajikan isu aktual yang dekat dengan pengalaman awal siswa terkait dengan materi dan penggunaan media teknologi pembelajaran yang sesuai dengan kondisi sekolah dan siswa. Hal ini dikarenakan isu aktual dan yang dekat dengan pengalaman awal siswa tidak termuat di buku ajar. Demikian pula, penggunaan teknologi untuk mendukung pembelajaran juga tidak termuat di buku ajar. Hal ini menjadikan guru secara kreatif menyiapkan isu lokal, praktis dan aktual guna mendukung pembelajaran materi tersebut. Guru juga menggunakan media teknologi pembelajaran untuk mendukung pembelajaran materi dengan menyesuaikan kondisi sekolah dan siswa.
\end{abstract}

Kata kunci: Pendidikan Pancasila dan Kewarganegaraan, materi pembelajaran, Bhinneka Tunggal Ika

\begin{abstract}
This study aims to identify and analyze the difficulties of junior high school civic education teachers in developing Bhinneka Tunggal Ika (the national slogan unity in diversity) learning materials based on actual issues. The method used is descriptive qualitative. Data was collected using interviews with informants from junior high school civic education teachers in Sukoharjo District and civics field experts, document analysis of civic education (PPKn) textbooks for junior high school and PPKn 2013 curriculum documents, supported by Focus Group Discussions. The results showed that the teacher had no difficulty developing the civic education materials of Bhinneka Tunggal Ika for junior high school because it was based on government textbooks and lesson plans developed by teachers' association (MGMP) of civic education subject for junior high school in Sukoharjo Regency. Difficulties are experienced when presenting actual issues that are close to students' initial experiences related to the materials and the use of instructional technology media that are appropriate to the conditions of the school and students. This is because actual issues that are close to students' initial experiences are not included in the textbook. Likewise, the use of technology to support learning is also not included in textbooks. This makes teachers creatively prepare local, practical and actual issues to support the learning of these materials. The teachers also
\end{abstract}


uses instructional technology media to support learning material by adjusting the conditions of the schools and students.

Keywords: civic education subject (PPKn), learning materials, Bhinneka Tunggal Ika

This work is licensed under the Creative Commons Attribution-ShareAlike 4.0 International License. (C2020 by the author(s).

\section{PENDAHULUAN}

Indonesia merupakan salah satu negara yang memiliki keragaman budaya terbesar di dunia. Hal ini terlihat dari adanya kelompok-kelompok besar etnis, agama, dan kelompok-kelompok budaya lain (Lestari, 2015) dan memiliki pluralisme budaya (Hefner, 2007). Keanekaragaman itu kemudian dilambangkan dengan sesanti Bhineka Tunggal Ika. Dengan demikian, sikap menghargai dan menghormati perbedaan dan keragaman penting dilakukan oleh segenap warga bangsa. Sikap tersebut tidak hanya berhenti dalam kesadaran tetapi hendaknya berlanjut dalam perilaku dan tindakan. Dalam pendidikan, tujuan pembelajaran bukan hanya pengetahuan (kognitif) tetapi berlanjut pada tumbuhnya kesadaran atau sikap (affective) dan juga pada tindakan (psikomotor). Dalam istilah Ki Hajar Dewantara, pendidikan itu harus "ngerti, ngrasa dan nglakoni" (KH Dewantara, 2013).

Kesadaran untuk menghargai dan menghormati keragamaan dan perbedaan, khususnya pada siswa dapat dikembangkan melalui pembelajaran akan pentingnya keragaman dan identitas bangsa Indonesia, misalnya melalui pelajaran PPKn yang memuat materi Bhinneka Tunggal Ika, sebagai wujud filosofi kesatuan yang melandasi dan mewarnai keberagaman kehidupan bermasyarakat, berbangsa, dan bernegara (Kemdikbud, 2016). Materi Bhinneka Tunggal Ika memiliki peran penting sebagai media guru guna membangun dan mengembangkan sikap menghargai dan menghormati keragaman bangsa. Pancasila dan Bhinneka Tunggal Ika dipandang mampu menanggulangi politik identitas yang muncul dalam diri warga (Nugroho, 2018). Hasil penelitian menunjukkan bahwa implementasi nilai-nilai Bhinneka Tunggal Ika di sekolah dapat dilakukan dengan melakukan penugasan membangun sikap toleransi dan anti diskriminasi dengan teman sekolah. (Setyaningsih, 2017). Pelajaran PPKn 2013 memiliki empat ruang lingkup yakni Pancasila, UUD 1945, Negara Kesatuan Republik Indonesia (NKRI), dan Bhinneka Tunggal Ika. Dalam buku Sosialisasi Empat Pilar Berbangsa dan Bernegara (MPR, 2012), uraian materi Bhinneka Tunggal Ika lebih sedikit dibanding tiga materi lainnya. Dengan demikian patut diduga bahwa materi Bhinneka Tunggal Ika masih sedikit dikembangkan sebagai materi ajar sehingga guru PPKn masih mengalami kesulitan dalam mengembangkan materi tersebut, padahal guru PPKn memiliki peran penting dalam membangun karakter siswa, misalnya karakter kebangsaan dan demokratis. (Fauzi, et al., 2013).

Namun demikian, guru sebagai salah satu faktor yang turut menentukan keberhasilan belajar siswa juga memiliki kekurangan. Penelitian Hartati (2014) menyebut bahwa kesulitan yang dialami guru PPKn lebih kepada kesulitan pengukuran keberhasilan siswa, yaitu benar tidaknya siswa memahami apa yang 
disampaikan oleh guru di kelas. Kesulitan juga dihadapi guru pada pemilihan metode pembelajaran serta terbatasnya buku penunjang pembelajaran. Buku penunjang sebagai sumber materi pembelajaran dipandang sebagai salah satu faktor kesulitan guru. Menghubungkan antara faktor guru dan materi pembelajaran ini penting dilakukan, yaitu penelitian tentang kesulitan apa saja yang dialami guru PPKn dalam mengembangkan materi Bhinneka Tunggal Ika. Selanjutnya hasil penelitian dapat menjadi dasar bagi perlunya pengembangan materi Bhinneka Tunggal Ika sebagai bahan ajar untuk siswa SMP berbasis isu aktual yang mampu mengembangkan sikap menghargai keragaman dan perbedaan Sejalan dengan latar dan permasalahan yang muncul di atas, maka artikel ini mencoba menjawab masalah penelitian yang dirumuskan sebagai kesulitan apa saja yang dialami guru PPKn SMP dalam upayanya mengembangkan materi aspek Bhinneka Tunggal Ika yang mampu meningkatkan kesadaran toleransi siswa dan apa upaya guru mengatasi kesulitan tersebut.

\section{METODE PENELITIAN}

Metode yang digunakan adalah kualitatif deskriptif. Dalam penelitian ini bentuk yang digunakan adalah penelitian kualitatif dengan metode deskriptif. Data yang akan dikumpulkan berupa kata-kata, dan kalimat, analisis dokumen maupun arsip yang memiliki arti yang lebih dari sekedar angka. Penelitian ini menggunakan metode deskriptif karena bermaksud untuk melakukan penyelidikan dengan memaparkan obyek dan subyek penelitian berdasarkan fakta yang tampak (Lexy J Moleong, 2017). Sumber data adalah guru PPKn jenjang SMP dan pakar bidang terkait materi dan pembelajaran PPKn sebagai informan, buku ajar PPKn jenjang SMP dan kurikulum PPKn 2013 sebagai pustaka. Teknik pengumpulan data yaitu wawancara, analisis dokumen dan focus group discussion (FGD).

Kelompok informan pertama adalah enam guru PPKn jenjang SMP yang mengampu di enam SMP berbeda di wilayah kabupaten Sukoharjo. Penetapan ini didasarkan pertimbangan agar data yang sama dapat diperoleh dari banyak informan sehingga memiliki keberagaman sumber data. Kelompok informan kedua adalah dua orang pakar bidang PKn yakni dosen PKn dari Universitas Negeri Yogkakarta dan Universitas Negeri Semarang. Pertimbangannya adalah dua orang pakar ini memang menguasai kurikulum PPKn dan selalu dilibatkan oleh Kementerian Pendidikan dan Kebudayaan dalam kegiatan penulisan buku ajar PPKn. Dokumen yang dianalisis adalah Rumusan Kompetensi Inti dan Kompetensi Dasar Mata Pelajaran PPKn jenjang SMP yang termuat di Permendikbud No 37 Tahun 2018 tentang Perubahan Atas Peraturan Menteri Pendidikan dan Kebudayaan Nomor 24 Tahun 2016 Tentang Kompetensi Inti dan Kompetensi Dasar Pelajaran pada Kurikulum 2013 pada Pendidikan Dasar dan Pendidikan Menengah. Dokumen kedua adalah buku ajar yang digunakan di sekolah yakni buku siswa PPKn SMP terbitan Kementerian Pendidikan dan Kebudayaan edisi revisi 2017. Focus group discussion untuk mengkonfirmasi temuan telah dilaksanakan pada tanggal 24 Agustus 2020 dengan menghadirkan informan guru dan pakar. FGD dimaksudkan untuk memperoleh masukan dari informan terkait sebagai bahan utama menyusun temuan penelitian sekaligus berfungsi sebagai member check. 
Analisis dilakukan secara interaktif (Miles dan Huberman, 2014), yaitu reduksi, penyajian, dan pengambilan simpulan. Simpulan yang dihasilkan adalah sajian tentang kesulitan guru PPKn dalam mengembangkan dan membelajarkan materi PPKn aspek Bhinneka Tunggal Ika dan upaya guru dalam mengatasi kesulitan yang muncul tersebut.

\section{HASIL PENELITIAN DAN PEMBAHASAN}

Untuk menjawab masalah ini, terlebih dahulu diidentifikasi materi aspek Bhinneka Tunggal Ika (BTI) pada pelajaran PPKn SMP. Adanya materi aspek Bhinneka Tunggal Ika (BTI) dapat kita temukan berdasarkan kurikulum PPKn SMP yakni Peraturan Menteri Pendidikan dan Kebudayaan No 37 Tahun 2018 tentang Perubahan atas Peraturan Menteri Pendidikan dan Kebudayaan Nomor 24 Tahun 2016 tentang Kompetensi Inti dan Kompetensi Dasar Pelajaran pada Kurikulum 2013 pada Pendidikan Dasar Dan Pendidikan Menengah.

Materi aspek Bhinneka Tunggal Ika (BTI) ditemukan pada kompetensi dasar pengetahuan atau KD 3. Rumusan kompetensi dasar berisi rumusan yang mencerminkan kompetensi dan materi pembelajaran di kelas VII, VIII dan IX yang terlihat pada Tabel 1 .

\section{Tabel 1. Rumusan Kompetensi Dasar Kelas VII, VIII, dan IX}

\begin{tabular}{|c|c|c|c|}
\hline Kelas & Kompetensi Dasar & $\begin{array}{c}\text { Rumusan } \\
\text { Kompetensi }\end{array}$ & Materi Pembelajaran \\
\hline \multirow[t]{2}{*}{ VII } & $\begin{array}{l}\text { 3.4 Mengidentifikasi keberagaman } \\
\text { suku, agama, ras dan antargolognan } \\
\text { dalam bingkai Bhinneka Tunggal } \\
\text { Ika. }\end{array}$ & Mengidentifikasi & $\begin{array}{l}\text { Keberagaman suku, } \\
\text { agama, ras dan } \\
\text { antargolongan dalam } \\
\text { bingkai Bhinneka } \\
\text { Tunggal Ika }\end{array}$ \\
\hline & $\begin{array}{l}3.5 \text { Menganalisis bentuk-bentuk } \\
\text { kerja sama dalam berbagai bidang } \\
\text { kehidupan di masyarakat. }\end{array}$ & Menganalisis & $\begin{array}{l}\text { Bentuk-bentuk kerja } \\
\text { sama dalam berbagai } \\
\text { bidang kehidupan di } \\
\text { masyarakat }\end{array}$ \\
\hline \multirow[t]{2}{*}{ VIII } & $\begin{array}{l}\text { 3.4 Menganalisa makna dan arti } \\
\text { kebangkitan nasional } 1908 \text { dalam } \\
\text { perjuangan kemerdekaan Republik } \\
\text { Indonesia. }\end{array}$ & Menganalisa & $\begin{array}{l}\text { Makna dan arti } \\
\text { kebangkitan nasional } \\
1908 \text { dalam perjuangan } \\
\text { kemerdekaan Republik } \\
\text { Indonesia }\end{array}$ \\
\hline & $\begin{array}{l}\text { 3.5 Memproyeksikan nilai dan } \\
\text { semangat Sumpah Pemuda tahun } \\
1928 \text { dalam bingkai Bhinneka } \\
\text { Tunggal Ika }\end{array}$ & Memproyeksikan & $\begin{array}{l}\text { Nilai dan semangat } \\
\text { Sumpah Pemuda tahun } \\
1928 \text { dalam bingkai } \\
\text { Bhinneka Tunggal Ika }\end{array}$ \\
\hline IX & $\begin{array}{l}\text { 3.4 Menganalisis prinsip persatuan } \\
\text { dalam keberagaman suku, agama, } \\
\text { ras, dan antargolongan (SARA), } \\
\text { sosial, budaya, ekonomi, dan } \\
\text { gender dalam bingkai Bhinneka }\end{array}$ & Menganalisis & $\begin{array}{l}\text { Prinsip persatuan } \\
\text { dalam keberagaman } \\
\text { suku, agama, } \\
\text { ras, dan antargolongan } \\
\text { (SARA), sosial, budaya, }\end{array}$ \\
\hline
\end{tabular}




\begin{tabular}{|c|c|c|}
\hline Tunggal Ika. & & $\begin{array}{l}\text { ekonomi, dan gender } \\
\text { dalam bingkai Bhinneka } \\
\text { Tunggal Ika }\end{array}$ \\
\hline $\begin{array}{l}\text { 3.5 Menganalisis prinsip harmoni } \\
\text { dalam keberagaman suku, agama, } \\
\text { ras, dan antargolongan (SARA) } \\
\text { sosial, budaya, ekonomi, dan } \\
\text { gender dalam bingkai Bhinneka } \\
\text { Tunggal Ika }\end{array}$ & Menganalisis & $\begin{array}{l}\text { Prinsip harmoni dalam } \\
\text { keberagaman suku, } \\
\text { agama, ras, dan } \\
\text { antargolongan (SARA) } \\
\text { sosial, budaya, ekonomi, } \\
\text { dan gender dalam } \\
\text { bingkai Bhinneka } \\
\text { Tunggal Ika }\end{array}$ \\
\hline
\end{tabular}

Sumber: Lampiran 19, Permendikbud No 37 Tahun 2018

Selanjutnya pada buku siswa maupun buku guru mapel PPKn juga ditemukan materi aspek Bhinneka Tunggal Ika (BTI), contohnya di buku siswa PPKn kelas VII edisi keempat terbitan Puskurbuk, Balitbang, Kemendikbud. Bagian daftar isi buku tersebut dimuat pada Gambar 1.

\section{Gambar 1. Tampilan Daftar Isi Buku PPKn Kelas VII}

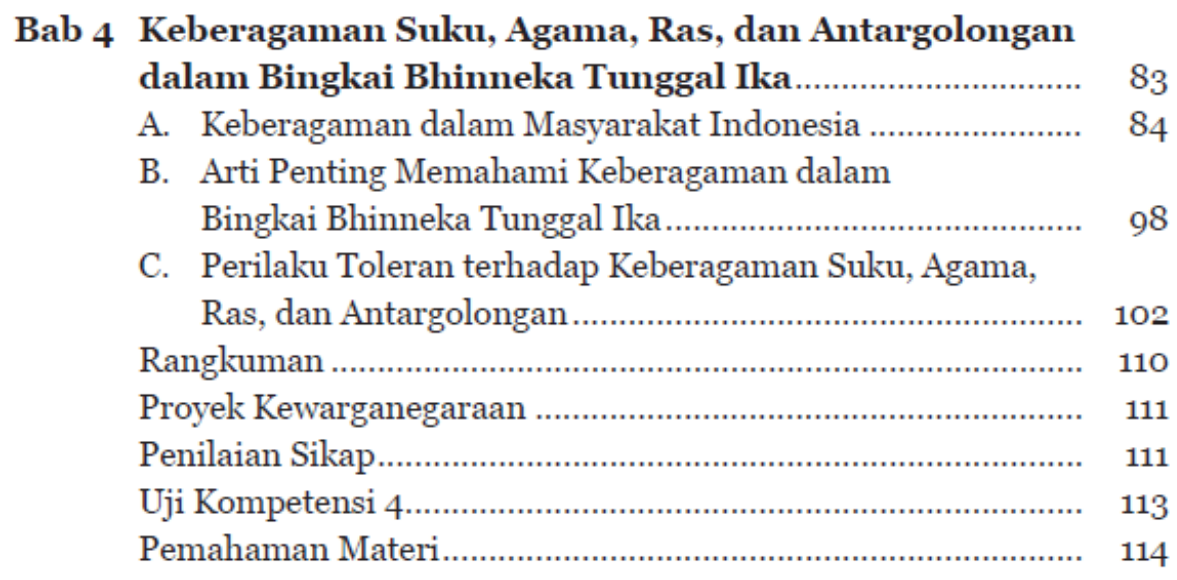

Bab 5 Kerjasama dalam Berbagai Bidang Kehidupan............. 115

A. Kerjasama dalam Berbagai Bidang Kehidupan .................. 116

B. Arti Penting Kerjasama dalam Berbagai Bidang Kehidupan .......................................................... 125

C. Mewujudkan Kerjasama dalam Berbagai Lingkungan Kehidupan .................................................... 127

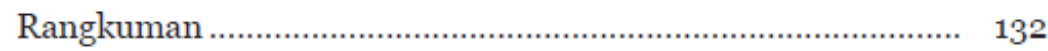

Proyek Kewarganegaraan ........................................................ 133

Penilaian Sikap.................................................................... 134

Uji Kompetensi 5 ............................................................. 134

Pemahaman Materi............................................................... 135

Sumber: PPKn VII, buku Siswa , Puskurbuk, Balitbang, Kemendikbud, 2017

Berdasarkan dua dokumen tersebut, adalah benar bahwa subtansi kajian aspek Bhinneka Tunggal Ika menjadi materi pembelajaran mata pelajaran PPKn 
jenjang SMP. Berdasarkan data, materi Bhinneka Tunggal Ika pelajaran PPKn jenjang SMP memuat enam butir penjabaran materi mulai dari kelas VII, VIII dan IX.

Menurut informan pakar 1, materi Bhinneka Tunggal Ika perlu dan bahkan penting diberikan kepada siswa mengingat adanya keragaman suku, tradisi dan budaya di Indoensia. Republik ini majemuk, sejak merdeka ada fakta bahwa kita berbeda. Apalagi sejak reformasi, angin kebebasan sangat marak. Ada gejala intoleran dan radikal. Materi ini dimaksudkan untuk membangun sikap toleransi dan merajut keragaman pada diri siswa. Tugas terpenting negara adalah mengintegrasikan dan meng-indonesia-kan anak Indonesia. Tujuannya adalah membentuk warga negara yang baik dan toleren.

Informan pakar 2 menyatakan bahwa materi Bhinneka Tunggal Ika berangkat dari realitas bangsa Indonesia sebagai bangsa yang majemuk dalam hal suku, agama, ras, dan antargolongan (SARA). Jadi materi tersebut sangat penting untuk diberikan, sebab dibutuhkan pemahaman tentang konsep keberagaman dan toleransi sebagai hubungan sebab-akibat dalam upaya mewujudkan persatuan (integrasi nasional).

Para informan guru secara umum juga menyatakan adanya materi Bhinneka Tunggal Ika pada pelajaran PPKn SMP yang dibelajarkan kepada siswanya. Menurutnya materi tersebut berisi materi keanekaragaman, sumpah pemuda, persatuan, dan SARA. Salah seorang informan guru menyatakan bahwa materi itu ada di kelas 7 dalam Bab 4, kelas 8 dalam Bab 5, dan kelas 9 dalam Bab 4 dan 5. Pada materi PPKn di kelas 8 yang dia ampu, ada materi BTI tentang "Sumpah Pemuda dalam Bingkai Bhinneka Tunggal Ika" terdiri dari: 1) Arti dan Makna Sumpah Pemuda dalam Perjuangan Kemerdekaan Republik Indonesia, 2) Memaknai Semangat Kejuangan Pemuda dalam Perjuangan Kemerdekaan Republik Indonesia, dan 3) Nilai Semangat Sumpah Pemuda Masa Sekarang. Dikatakan bahwa materi itu sudah sesuai dengan kurikulum dan oleh guru dibuatkan Rencana Pelaksanaaan Pembelajaran (RPP).

Berikut ini dicukilkan contoh RPP guru bagian identitas yang menunjukkan guru telah mengembangkan RPP yang bermuatan materi Bhinneka Tunggal Ika.

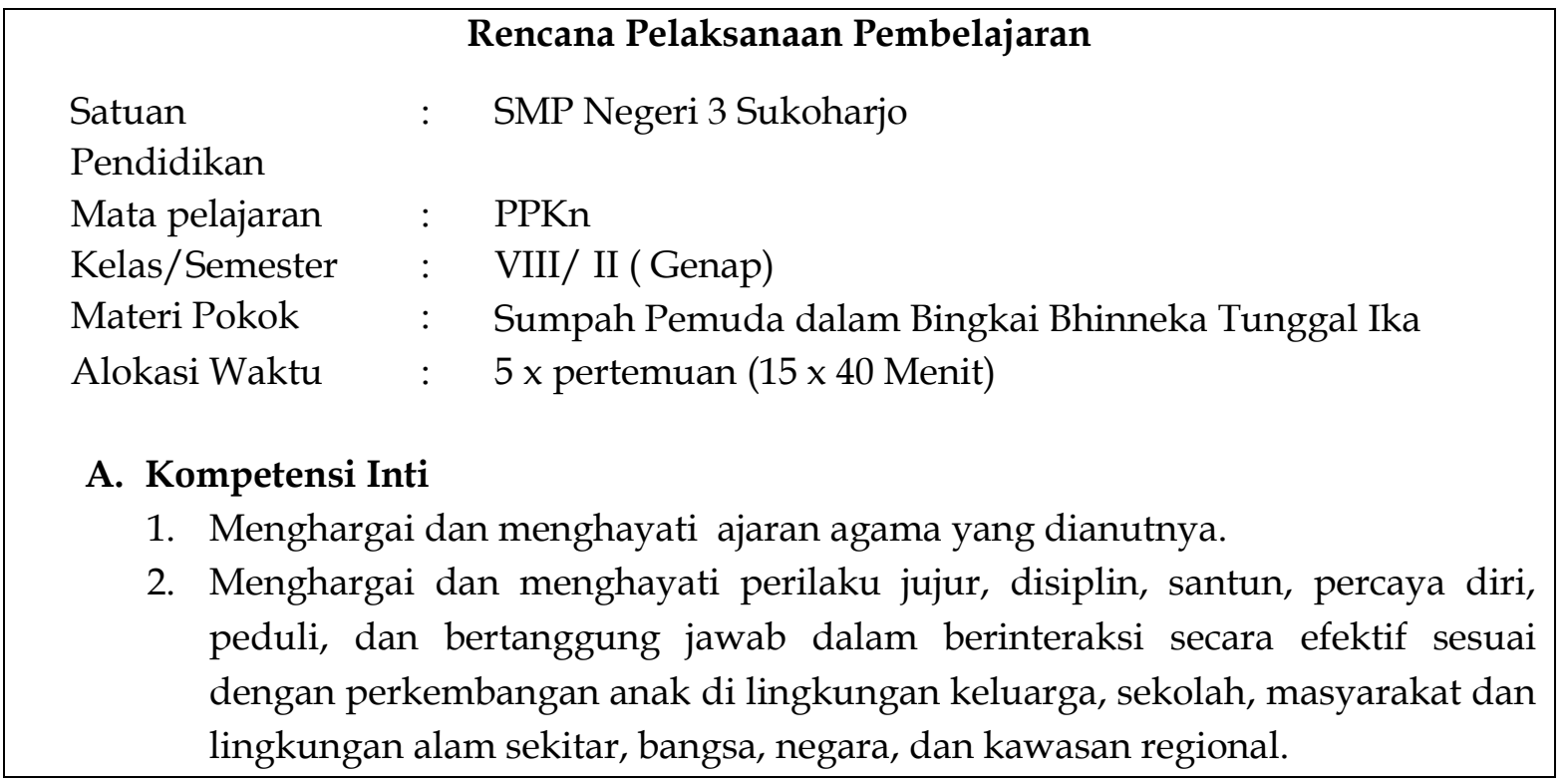




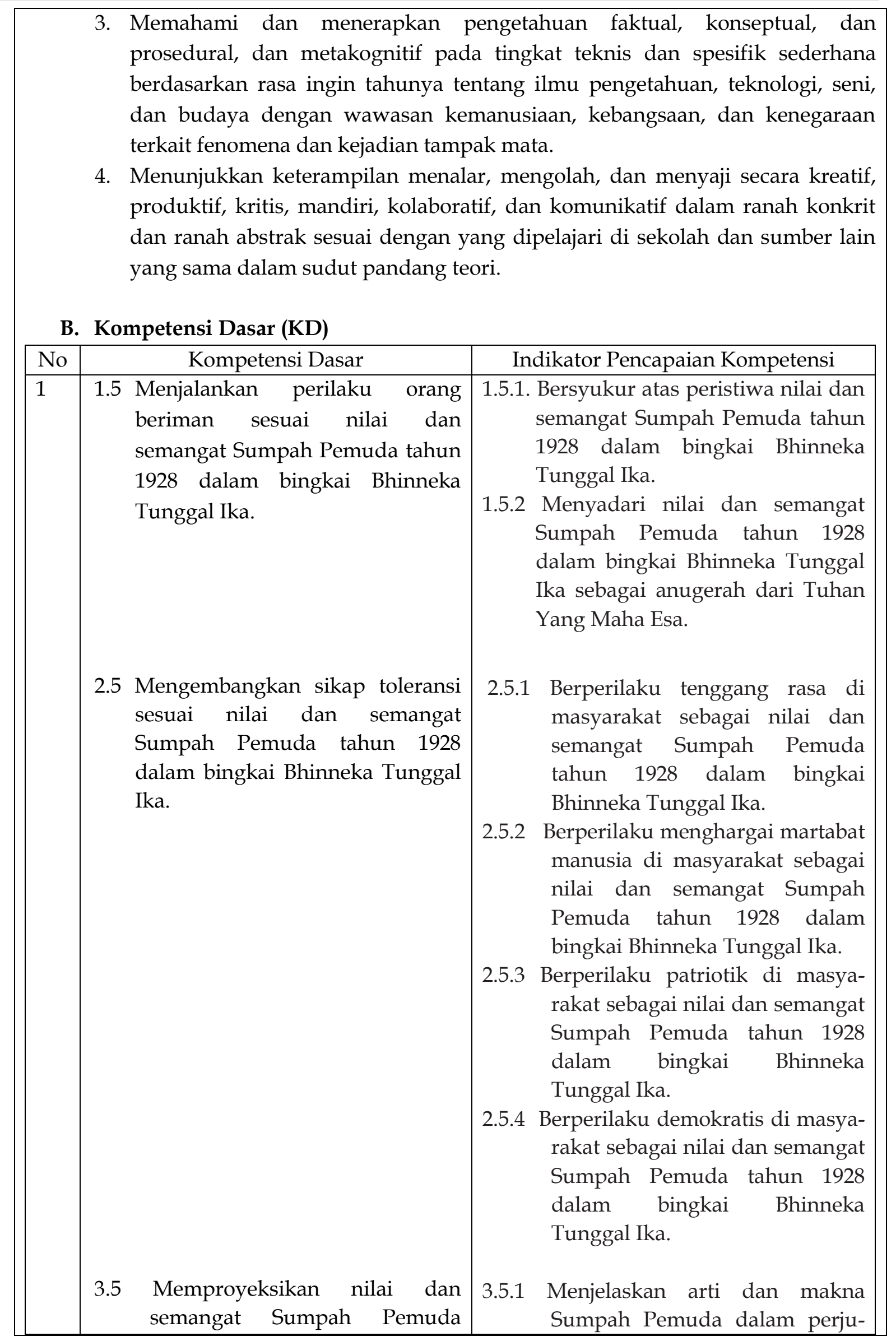




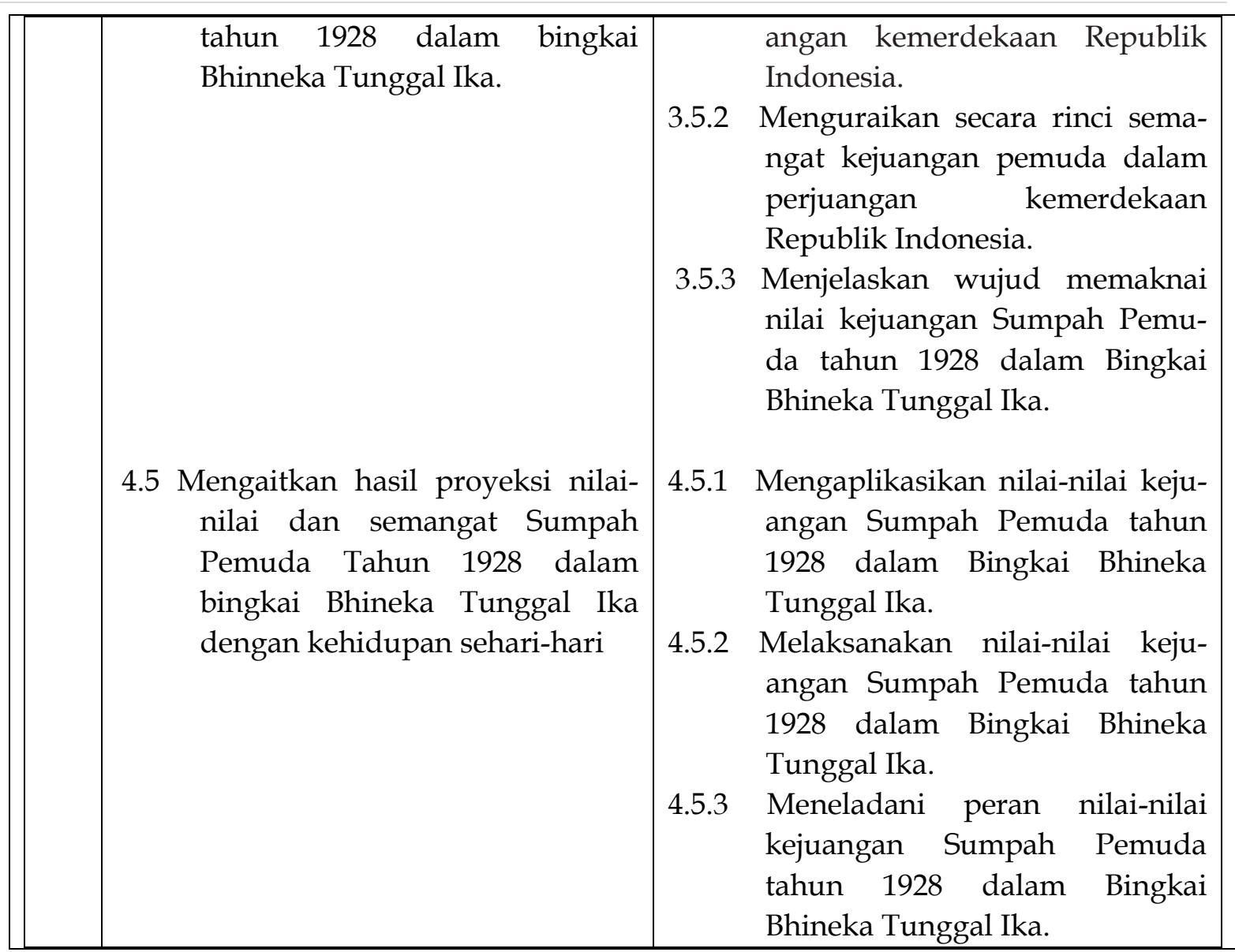

Sumber: dikutip dari RPP PPKn SMP VII, SMP N 3 Sukoharjo, 2019

Berdasarkan analisis contoh dokumen di atas, terlihat bahwa guru mengembangkan materi aspek Bhinneka Tunggal Ika melalui penyusunan RPP. Muatan itu dikembangkan oleh guru ke dalam rumusan indikator sebagai penjabaran dari KD (kompetensi dasar) dan KI (kompetensi inti). KD dari KI 1, KD dari KI2, KD dari KI3 dan KD dari KI4 telah dijabarkan ke rumusan indikator sebanyak 12 butir.

Setelah merumuskan indikator, guru mengembangkan muatan Bhinneka Tunggal Ika ke subjudul Materi Pembelajaran. Menurut guru, mereka menyusun materi di RPP tersebut dengan berpedoman pada buku teks pemerintah juga buku referensi dari penerbit lain. Menurut pengakuan guru pula, mereka tidak merasa kesulitan menemukan materi yang diamanatkan oleh Kompetensi Dasar dan Indikator. Berdasar hasil wawancara dengan informan guru, mereka umumnya tidak menyusun secara penuh RPP tersebut, tetapi sebagian besar lebih banyak menyalin dari file RPP dari sumber lain atau RPP dari MGMP PPKn SMP.

Materi aspek Bhinneka Tunggal Ika memang diakui oleh guru, ada dan telah diajarkan ke siswanya baik di kelas VII, VIII, dan IX pelajaran PPKn. Materi itu ada di kelas PPKn, seperti materi perihal keanekaragaman, keragaman suku, agama, ras dan budaya. Ada pula materi Bhinneka Tunggal Ika yang dikaitkan dengan materi Sumpah Pemuda. Seorang informan guru menyatakan sebagai berikut: "Untuk yang kelas VIII yang saya ampu, materi BTI tentang 'Sumpah Pemuda dalam Bingkai Bhinneka Tunggal Ika' terdiri dari; 1) Arti dan Makna Sumpah Pemuda dalam 
Perjuangan Kemerdekaan Republik Indonesia, 2) Memaknai Semangat Kejuangan Pemuda dalam Perjuangan Kemerdekaan Republik Indonesia dan 3) Nilai Semangat Sumpah Pemuda Masa Sekarang."

Informan guru tidak merasa mengalami kesulitan ketika mencari sumber bahan tentang Bhinneka Tunggal Ika ini. Mereka telah mendapatkan materi tersebut di buku guru dan buku siswa terbitan Kemendikbud. Sebagian guru menggunakan buku teks terbitan penerbit partikular dan buku buatan kelompok MGMP yang berwujud SBA (Suplemen Bahan Ajar).

Dalam hal proses pembelajaran, informan guru juga merasa tidak mengalami kesulitan dalam membelajarkan materi ini. Kendala yang mungkin adalah pemanfataan sumber belajar dengan teknologi dalam kelas. Oleh karena itu guru umumnya membekali proses pembelajarannya dengan bantuan teknologi pembelajaran, seperti yang diungkapkan oleh informan guru sebagai berikut:

"Untuk memudahkan siswa memahami materi BTI biasanya guru menjelaskan materi dengan power point, video pembelajaran, memberikan contoh isu faktual yang terjadi dan siswa diberi kesempatan untuk menerangkan materi yang mereka kuasai untuk diterangkan kepada siswa lainnya. Siswa yang belum menguasai materi diberi kesempatan untuk membuat pertanyaan atau bertanya materi yang belum dikuasai." (Dok wawancara, Agustus 20)

Mengenai respon siswa saat diberikan pembelajaran materi Bhinneka Tunggal Ika, informan guru mengemukakan bahwa respon atau tanggapan siswa bisa beragam, tergantung pada konteks materi tersebut dibelajarkan. Siswa bisa termotivasi dan bersemangat jika materi yang diberikan kontekstual dengan kehidupan anak dan sedang menjadi masalah yang "trending topic", misalnya isu tentang radikalisme. Siswa juga senang jika materi itu dikaitkan dengan dunia yang dihadapinya, misalnya adanya kelompok-kelompok karena berbeda pilihan simpatisan sepak bola; ada yang jakmania dan ada yang ikut pasopati, dan sebagainya.

Guna meningkatkan sikap tertarik dan bersemangat dalam belajar materi ini, guru juga berupaya menampilkan isu yang sedang dibicarakan dengan ditunjang tugas yang mengaktifkan siswa. Seorang informan guru menyatakan sebagai berikut:

“Untuk menambah wawasan dan pengetahuan tentang BTI siswa biasanya diberi tugas guru untuk melaksanakan diskusi tentang materi yang dibahas, dihubungkan dengan isu aktual yang sedang terjadi. Selain itu siswa diberi tugas mencari referensi materi di internet dan koran untuk dijadikan bahan tambahan materi diskusi dan membuat kliping untuk penugasan keterampilan." (Dok wawancara, Augustus 2020)

Informan guru lain menyatakan bahwa pada dasarnya setiap siswa memiliki respon yang berbeda-beda dalam menerima materi Bhinneka Tunggal Ika, sehingga guru harus menyesuaikan penyampaian materi kepada siswanya. Setiap guru juga memiliki kemampuan yang berbeda dalam menyampaikan materi Bhinneka Tunggal Ika. Untuk menarik perhatian siswa mengikuti materi Bhinneka Tunggal Ika, siswa diberi ataupun diputarkan film tentang keberagaman masyarakat Indonesia, isu faktual yang terjadi atau apapun topik yang ada hubungannya 
$106 \mid$ Winarno, et al

Analisis Kesulitan Guru...

dengan materi. Biasanya siswa lebih tertarik mengikuti materi Bhinneka Tunggal Ika dengan tayangan power point dan video pembelajaran daripada siswa membaca maupun mendengarkan materi dari gurunya.

Perihal kekurangan materi aspek Bhinneka Tunggal Ika di buku teks siswa, guru menyatakan bahwa kekurangannya adalah tidak ada tugasnya atau kegiatan yang bisa dilakukan/dipraktekkan dalam kelas yang isinya homogen untuk melatih sikap toleransi siswa. Ketika kelas berisikan siswa yang heterogen dalam SARA, maka siswa akan terlatih dan terbiasa menghadapi teman-teman yang berbeda. Kasus kelas di sekolah-sekolah daerah, homogenitas masih tinggi, sehingga siswa jarang dihadapkan langsung dengan segala jenis perbedaan yang ada. Jadi menurut informan guru, sulit untuk menyatakan bahwa materi Bhinneka Tunggal Ika bisa mengembangkan sikap toleransi karena pada kenyataannya siswa berada di kelas yang kebanyakan bersifat homogen. Namun pada kenyataan yang dialami guru, siswa memang sudah terbiasa bertoleransi dalam kehidupan di kelas dan di sekolah. Hal ini terbukti dari adanya saling menghormati sesama teman, tidak membedakan dalam bergaul, tidak mudah terpengaruh jika ada berita kejadian tentang pertikaian SARA, dan kerukunan siswa yang tetap terjaga.

Perihal bagaimana sebaiknya materi Bhinneka Tunggal Ika itu bisa menarik perhatian siswa, informan guru umumnya menyarankan perlunya dua hal. Saran pertama yaitu penyampaian materi disertai isu aktual yang tengah berkembang atau pengalaman yang memang menjadi dunia anak atau siswa SMP. Contoh yang diajukan guru adalah isu tentang radikalisme yang menurutnya sebagai contoh paham yang tidak toleren. Contoh lain adalah adanya perbedaan kelompok remaja karena perbedaan pilihan akan kecintaannya dengan klub sepak bola. Isu yang dipandang menarik siswa SMP adalah isu tingkat lokal. Kedua, materi Bhinneka Tunggal Ika disajikan dengan bantuan teknologi atau memanfaatkan penggunaan teknologi pembelajaran, misalnya dalam bentuk tampilan power point, menyimak video pembelajaran atau mencari kliping di internet.

Berdasarkan temuan di atas, dapat dilihat bahwa pengembangan materi pembelajaran tentang Bhinneka Tunggal Ika pada jenjang SMP memang diperlukan. Bhinneka Tunggal Ika merupakan pernyataan jiwa dan semangat bangsa Indonesia yang mengakui realitas bangsa yang majemuk, namun tetap menjunjung tinggi kesatuan. Bhinneka Tunggal Ika merumuskan dengan tegas adanya harmoni antara kebhinnekaan dan ketunggalikaan, antara keanekaan dan keekaan, antara hal banyak dan hal satu, atau antara pluralisme dan monisme. Pengembangan materi tentang Bhineka Tunggal Ika ini tentunya harus disertai dengan isu aktual yang tengah berkembang atau pengalaman yang memang menjadi dunia siswa SMP.

Hal ini sesuai dengan pendapat Melaningrum (2018) bahwa pengembangan perilaku perlu didasarkan pada nilai dan moral yang mencerminkan karakter diri, masyarakat, dan bangsa, menanamkan sikap berorientasi kepada kehidupan masa kini dan masa depan berdasarkan pengalaman masa lampau, memahami dan mampu menangani isu-isu kontroversial untuk mengkaji permasalahan yang terjadi di lingkungan masyarakatnya.

Penerapan model isu kontroversial ini diharapkan mampu membangkitkan kemampuan berpikir kritis siswa dalam memahami isu-isu dan permasalahan 
Bhineka Tunggal Ika yang terjadi di lingkungan kehidupan siswa dan juga siswa diharapkan mendapatkan hasil yang memuaskan. Siswa diajak mampu mengambil keputusan dengan alasan atau pertimbangan yang rasional didukung dengan fakta, konsep, dan prinsip yang akurat.

Membangun toleransi harus menjadi prioritas, terutama dalam konteks masyarakat yang plural dan heterogen. Pemahaman atas pentingnya toleransi penting dalam rangka membangun sikap toleransi antarsiswa dalam Bingkai Bhineka Tunggal Ika. Nilai-nilai Bhinneka Tunggal Ika telah diimplementasikan dengan baik oleh siswa dalam perilaku keseharian mereka di sekolah. Mereka dapat berinteraksi dengan siswa tanpa membedakan latar belakang mereka. Sekalipun muncul konflik, tetapi konflik itu dilatarbelakangi oleh ego mereka sendiri, bukan karena perbedaan etnis, budaya, gender maupun paham keagamaan. Mereka juga dapat membangun sikap toleransi antar teman. Menurut Lembaga Ketahanan Nasional Republik Indonesia (2011), nilai-nilai yang terkandung dalam Bhinneka Tunggal Ika meliputi:

1) Nilai Toleransi, merupakan suatu sikap yang mau memahami orang lain sehingga komunikasi dapat berlangsung dengan baik;

2) Nilai Keadilan, merupakan suatu sikap mau menerima haknya dan tidak mau mengganggu hak orang lain;

3) Nilai Gotong Royong/kerjasama, merupakan suatu sikap untuk membantu pihak/orang yang lemah agar sama-sama mencapai tujuan.

Guru mengakui bahwa masih ada kendala dalam proses pembelajaran. Kendala itu antara lain dalam membangun minat siswa dan membangun sikap toleransi antar siswa. Masih ada siswa yang kurang memiliki minat belajar, dan tidak memiliki sikap keberagamaan yang inklusif. Dalam proses pembelajaran, guru tidak melakukan diskriminasi terhadap siswanya yang berbeda latar belakang. Guru berusaha merangkul semua agar terjalin hubungan yang demokratis dan menyenangkan saat proses pembelajaran berlangsung.

Toleransi harus didukung oleh cakrawala pengetahuan yang luas, sikap terbuka, dialog, kebebasan berpikir dan beragama (Casram, 2016). Melalui pengetahuan yang luas maka cara pandang akan suatu hal akan berbeda sehingga akan mempengaruhi sikap toleransi. Toleransi juga dapat diartikan sebagai sikap positif dalam menghargai orang lain dengan menggunakan kebebasan hak asasi sebagai manusia dan makhluk sosial. Dengan sikap saling menghargai dan menghormati maka akan tercipta suasana yang aman dan tenteram serta meminimalisir perpecahan di antara minoritas dan mayoritas. Sikap toleransi merupakan harmoni dalam perbedaan (Svanberg, 2014).

Toleransi yang tinggi diharapkan mampu menciptakan sebuah tatanan kehidupan yang pluralis dengan baik, saling menghargai dan menghormati perbedaan demi menjaga persatuan dan kesatuan Indonesia. Tetapi sebaliknya, jika tidak memiliki toleransi maka tidak tertutup kemungkinan timbulnya perilaku destruktif yang ada di dalam masyarakat yang akan mengancam persatuan dan kesatuan Indonesia. Istilah toleransi dapat menyiratkan sikap dari sebuah anggota terhadap kelompok sosial. Toleransi sosial digunakan untuk mengukur toleransi terhadap kaum minoritas (Svanberg, 2014). Hasil penelitian yang dilakukan oleh 
$\mathbf{1 0 8} \mid$ Winarno, et al

Analisis Kesulitan Guru...

Juditha (2015) menunjukan bahwa jika di dalam kontak sosial terjadi konflik maka ada fungsi komunikasi antar etnis yang tidak dilakukan dengan baik.

Di dalam teori toleransi terdapat beberapa dimensi yaitu toleransi antaretnis, toleransi sosial dan toleransi dalam kepribadian (Sztejnberg dan Jasinnski, 2016). Dimensi antaretnis meliputi sikap terhadap perbedaan mencakup ke dalam kaum mayoritas dan minoritas baik ras maupun etnis. Contohnya adalah saling memahami perbedaan baik dalam perbedaan warna kulit ataupun letak geografis. Dalam bermasyarakat tidak jarang perbedaan gaya bahasa menjadi salah satu faktor yang disalahartikan (Nugroho dkk, 2012). Selanjutnya ada dimensi toleransi sosial meliputi kontak sosial yang terjadi di tengah masyarakat akan sebuah perbedaan melalui pola keterbukaan kontak sosial sehingga menciptakan sebuah komunikasi antaretnis yang baik. Dimensi toleransi dalam kepribadian meliputi penggambaran mengenai realitas lingkungan yang berada pada sebuah kebudayaan yang multikultural, contohnya adalah sebuah perlakuan di antara kedua etnis yang saling menghakimi satu sama lain.

Adapun untuk mewujudkan pendidikan yang dapat menanamkan sikap toleransi di masyarakat adalah dengan: 1) memahami perspektif setiap orang; 2) menumbuhkan sikap empati; 3) selalu meminta penjelasan; 4) menghargai perbedaan; dan 5) mempelajari mengenai masyarakat dan budaya yang lain. Selain itu, upaya pendidikan untuk menanamkan sikap toleran di masyarakat dilakukan melalui: 1) pendidikan multikultural dan karakter; 2) pendidikan berwawasan kebangsaan; dan 3) manajemen pendidikan yang profesional (Muawanah, 2018). Peranan mata pelajaran PPKn dalam membina sikap toleransi antarsiswa yaitu harapan agar siswa tersebut saling bergaul, saling menghormati, dan saling membantu antara sesamanya.

Selanjutnya materi Bhinneka Tunggal Ika yang telah dikembangkan juga perlu disajikan dengan bantuan teknologi, mengingat sekarang memasuki era perkembangan teknologi yang begitu pesat sehingga pendidikan mengalami perubahan yang signifikan dari zaman ke zaman.

Menurut Budiana (2015) manfaat tekonologi informasi komunikasi dalam rangka mendukung pelaksanaan pembelajaran adalah 1) Meningkatkan kualitas pembelajaran; 2) Memperluas akses terhadap pendidikan dan pembelajaran; 3) Membantu memvisualisasikan ide-ide abstrak; 4) Mempermudah pemahaman materi yang sedang dipelajari; 4) Menampilkan materi pembelajaran menjadi lebih menarik; dan 5) Memungkinkan terjadinya interaksi antara pembelajaran dengan materi yang sedang dipelajari.

Pemanfaatan TIK dalam pembelajaran menjadi tuntutan yang mendesak di abad 21 ini, derasnya arus informasi membuat guru bukanlah satu-satunya sumber belajar. Upaya strategis yang perlu dilakukan oleh guru adalah dengan meningkatkan kualitas proses dan hasil belajar siswa dengan memanfaatkan TIK sebagai sumber belajar yang menunjang pembelajaran. Menurut Siahaaan (2010) pentingnya pemanfaatan TIK dalam pembelajaran antara lain: 1) membuat konkrit konsep yang abstrak; 2) membawa objek yang sukar didapat ke dalam lingkungan belajar; 3) menampilkan objek yang terlalu besar; 4) memungkinkan siswa berinteraksi langsung dengan lingkungannya; 5) memungkinkan keseragaman 
persepsi dan pengamatan bagi pengalaman belajar siswa; 6) membangkitkan motivasi belajar; dan 7) menyajikan informasi belajar secara konsisten.

Pengembangan materi tentang Bhineka Tunggal Ika pada jenjang SMP sangat penting dilakukan mengingat masih terdapat keterbatasan dalam materi Bhineka Tunggal Ika yang tersaji dalam buku siswa, kemudian juga diperlukan keterampilan guru dalam memanfaatkan teknologi informasi dan komunikasi dalam menyajikan isu-isu aktual yang berkaitan dengan contoh-contoh kasus pelanggaran dan pelaksanaan Bhineka Tunggal Ika dalam masyarakat di Indonesia. Dari sisi siswa, kemampuan penguasaan teknologi informasi sangat penting untuk dikuasai mengingat ketersediaan sumber belajar non cetak lebih banyak daripada sumber belajar cetak, sehingga siswa harus memiliki kemampuan untuk mencari, memilih, dan memilah informasi yang dibutuhkan di antara banyaknya informasi yang tersedia di internet terutama yang berkaitan dengan isu-isu aktual Bhinneka Tunggal Ika.

Temuan penelitian menunjukkan bahwa kesulitan guru dalam mengembangkan materi Bhinneka Tunggal Ika adalah pada saat proses pembelajaran di mana pemuatan isu-isu aktual yang berkaitan dengan materi masih belum mampu menarik minat siswa. Hal ini dikarenakan isu yang diangkat umumnya adalah apa yang ada di buku siswa atau suplemen bahan ajar. Kasus yang ada di buku umumnya tidak dekat dengan siswa di sekolah yang bersangkutan. Menyadari hal tersebut guru mensiasatinya dengan penggunaan isu lokal yang terkait dengan pengalaman siswa, misalnya isu tentang bentrokan antar pendukung sepak bola di wilayah tersebut. Isu tersebut dikandung maksud memberikan gambaran masih adanya sikap intolerensi di kalangan siswa atau generasi muda. Kesulitan lain adalah pemanfaatan teknologi informasi dalam pembelajaran yang bisa sama-sama dilakukan oleh guru maupun siswa dan juga mendapatkan fasilitasi sarana dari pihak sekolah. Guru akan menggunakan LCD dan laptop, namun sarana tersebut belum semua ada di ruang kelas. Atas hal tersebut, guru mensiasatinya dengan menggunakan media yang mungkin misal dengan adanya mading di ruang kelas, atau membawa media koran ke kelas.

Pengembangan materi dalam bentuk bahan ajar yang interaktif tidak sebatas buku penting untuk dijalankan. Hal demikian sejalan dengan pendapat bahwa materi atau bahan ajar (instructional material) menjadi faktor penting untuk mewujudkan tujuan dalam proses pembelajaran dan mendorong semangat dan motivasi siswa untuk lebih giat belajar. Ia pada dasarnya adalah "isi" dari kurikulum itu sendiri (Ruhimat, 2011). Jenis bahan ajar mencakup cetak maupun noncetak. Bahan ajar cetak berbentuk modul, handout, buku, brosur, dan lembar kerja siswa. Sedangkan noncetak meliputi bahan ajar dengar (audio) dan pandang dengar (audio visual). (Lestari, 2013). Pengembangan bahan ajar sebaiknya memperhatikan prinsip self-instruction, self-contained, stand alone, adapatif dan user friendly (Daryanto, 2013).

Selanjutnya pengembangan materi Bhinneka Tunggal Ika pada mata pelajaran PPKn SMP perlu dilakukan dalam rangka memperkaya materi ajar Bhinneka Tunggal Ika, melengkapinya dengan isu aktual yang berbasis lokal dan memudahkan pemenuhan bahan ajar materi yang bersifat daring atau e-book. Hal 
110 | Winarno, et al

Analisis Kesulitan Guru...

demikian sejalan dengan pendapat bahwa materi ajar dapat dikembangkan berdasarkan pada tema atau isu aktual. Hal ini akan menimbulkan daya tarik, memudahkan pemahaman dan sekaligus memberikan pencerahan terkait dengan realitas yang dihadapi (Machmud, 2017). Materi ajar PPKn akan menarik siswa apabila disisipi dengan isu kewarganegaraan, utamanya isu yang sifatnya lokal dan praktis, sesuai dengan pendapat bahwa isu kewarganegaraan didasarkan atas empat jenis yakni isu universal, advokasi, selektif dan praktis (Muhibbin \& Sumardjoko, 2016).

\section{SIMPULAN}

Berdasarkan temuan dan pembahasan di atas, dapat disimpulkan bahwa guru PPKn pada dasarnya tidak mengalami kesulitan mengembangkan materi pembelajaran aspek Bhinneka Tunggal Ika terutama saat menyusunnya di Rencana Pelaksanaan Pembelajaran (RPP) dan pengembangannya di kelas. Guru mengembangkan materi di lampiran RPP dan menyusun materi dalam bentuk bahan tayang. Hal ini dikarenakan buku ajar dan suplemen bahan ajar yang digunakan sudah memiliki materi ajar yang cukup untuk kebutuhan siswa SMP. Kesulitan yang dialaminya adalah pada saat menghadirkan isu aktual yang dekat dengan pengalaman siswa sesuai dengan materi Bhinneka Tunggal Ika. Hal ini dikarenakan isu aktual pada umumnya jarang termuat dalam buku ajar. Kalaupun ada, isu yang termuat kurang sejalan dengan pengalaman kontekstual siswa di sekolah tersebut berada. Kesulitan lain adalah kesulitan memilih dan menggunakan media dan teknologi informasi yang mampu menarik perhatian dan minat siswa yang juga dimiliki oleh sekolah yang bersangkutan. Upaya yang dilakukan adalah dengan memunculkan isu aktual yang dekat dengan pengalaman siswa di wilayah tersebut, seperti kasus bentrokan antar pendukung sepak bola. Dalam menggunakan media informasi teknologi, guru memanfaatkan media koran yang memuat isu terkait materi Bhinneka Tunggal Ika. Di ruang kelas yang memiliki LCD, guru memanfaatkannya untuk pemutaran film atau video pembelajaran dan tayangan materi. Selanjutnya pengembangan materi Bhinneka Tunggal Ika pada mata pelajaran PPKn SMP perlu dilakukan dalam rangka memperkaya materi ajar di buku siswa. Pengembangan materi dilakukan dengan cara melengkapinya dengan isu aktual yang berbasis lokal. Materi ini dimuat dalam bentuk e- materi atau materi daring. Hal demikian dimaksudkan untuk memudahkan pemenuhan kebutuhan materi pembelajaran baik oleh guru maupun siswa.

\section{REFERENSI}

Budiana. (2015). Pemanfaatan Teknologi Informasi dan Komunikasi Dalam Pembelajaran Bagi Para Guru Smpn 2 Kawali Desa Citeureup Kabupaten Ciamis. Jurnal Aplikasi Ipteks untuk masyarakat. 4 (1). 59-62.

Casram. (2016). Membangun Sikap Toleransi Beragama Dalam Masyarakat Plural. Jurnal Ilmiah Agama dan Sosial Budaya. Vol 1, No 2 Juli 2016: 187-198.

Daryanto. (2013). Menyusun Modul (Bahan Ajar untuk Persiapan Guru dalam Mengajar. Yogyakarta: Penerbit Gava.

Fauzi, Fadil Yudia; Arianto, Ismail; Solihatin, E. (2013). Peran Guru Pendidikan Pancasila Dan Kewarganegaraan Dalam Upaya Pembentukan Karakter 
Peserta Didik. Jurnal Ppkn Unj Online.

Gina Lestari. (2015) Bhinneka Tunggal Ika: Khasanah Multikultural Indonesia di tengah Kehidupan Sara. Jurnal Pendidikan Pancasila dan Kewarganegaraan,Th. 28, Nomor 1, Pebruari 2015.

Hartati, Erma Dwi. (2014) Identifikasi Kesulitan-Kesulitan Guru Dalam Proses Pembelajaran PKn di SMA Patria Kabupaten Bantul Yogyakarta dalam Academy Of Education Journal. Pendidikan Pancasila Dan Kewarganegaraan. 5 (2) Juli 2014.

Hefner, Robert W. (2007) Politik Multikulturalisme: Menggugat Realitas Kebangsaan. Terjemahan oleh Bernardus Hidayat dari judul asli The Politics of Multiculturalism, Pluralism and Citizenship in Malaysia, Singapore, and Indonesia. Yogyakarta: Kanisius.

Ika Lestari. (2013.) Pengembangan Bahan Ajar Berbasis Kompetensi. Jakarta: Penerbit Indeks.

Juditha, Cristiany. (2015). Stereotip dan Prasangka dalam Konflik Etnis Tionghoa dan Bugis Makasar. Jurnal Ilmu Komunikasi. vol 12, no. 1, Juni 2015: 87-104.

Kemdikbud. (2016). Pendidikan Pancasila dan Kewarganegaraan SMP VII. Buku Guru. Jakarta: Kementrian Pendidikan dan Kebudayaan.

Ki Hajar Dewantara. (2013). Buku Pertama Pendidikan. Yogyakarta: Majelis Luhur Taman Siswa.

Machmud A Rasyid. (2017). Penguatan Kompetensi Profesional Guru Untuk Membentuk Warganegara Yang Cerdas Melalui Pilihan Isu E Tema Baru. Artikel Prosiding Semnas AP3KnI Jateng dan PPKn UNS, tanggal 25 Nopember 2017.

Melaningrum. (2018). Menguatkan Karakter Bhineka Tunggal Ika Melalui Pembelajaran di Kelas. Jurnal Citizenship. 4 (1).

Miles, M.B, Huberman, A. M, \& Saldana, J. (2014). Qualitative Data Analysis, Method Sourcebook, Edition 3 . USA: Sage.

Moleong, Lexy J. (2017). Metodologi Penelitian Kualitatif. Edisi revisi. Bandung: Rosda

Muawanah. (2018). Pentingnya Pendidikan untuk Tanamkan Sikap Toleran di Masyarakat. Jurnal Vijjacariya. 5 (1).

MPR RI. (2012). Empat pilar kehidupan berbangsa dan bernegara. Jakarta : Sekretariat MPR RI.

Muhibbin, A., \& Sumardjoko, B. (2016). Model pembelajaran Pendidikan Kewarganegaraan berbasis isu-isu kontroversial di media massa untuk meningkatkan sikap demokrasi mahasiswa dan implikasinya bagi masyarakat madani. Jurnal Pendidikan Ilmu Sosial, 26(1), 1-10.

Nugroho, R. H. (2018). Peranan Pancasila Dan Bhineka Tunggal Ika Dalam Menanggulangi Politik Identitas. Prosiding Senaspolhi.

Nugroho A. B, Lestari P dan Wiendijarti I. (2012). Pola Komunikasi Antarbudaya Batak dan Jawa di Yogyakarta. Jurnal Komunikasi. Volume 1, Nomor 5, Juli 2012.

Ruhimat, Toto dkk. (2011). Kurikulum dan Pembelajaran. Jakarta: Rajawali Press.

Setyaningsih, U. (2017). Implementasi Nilai-Nilai Bhinneka Tunggal Ika pada Siswa Kelas Vii SMP Negeri 1 Surakarta pada Tahun Pelajaran 2016/2017. Uiversitas Muhammadiyah Surakarta. 
112 | Winarno, et al

Analisis Kesulitan Guru...

Sukmadinata, Nana Syaodih. (2013). Metode Penelitian Pendidikan. Bandung : PT. Remaja Rosdakarya.

Sugiyono (2011). Metode penelitian kuntitatif kualitatif dan RED. Bandung. Alfabeta.

Svanberg, Lisa. (2014). Tolerance of Diversity and the Influence of Happiness. Bachelor Thesis in Economics. Karlstad Business School.

Sztejnberg. A and Jasinnski. T. L. (2016). Measurement of the tolerance general level in the higher education students. International Journal of Latest Research in Humanities and Social Science (IJLRHSS). Volume 01 - Issue 04. 